\title{
PENGEMBANGAN BUKU AJAR MATEMATIKA KELAS X SMA BERBASIS HOTS
}

\author{
Rifdah Kurniawan ${ }^{1}$, Ishaq Nuriadin ${ }^{2}$, Benny Hendriana ${ }^{3}$ \\ ${ }^{1}$ Universitas Muhammadiyah Prof. DR. HAMKA \\ rifdaahkurniawn@gmail.com \\ ${ }^{2}$ Universitas Muhammadiyah Prof. DR. HAMKA \\ ishaq_nuriadin@yahoo.co.id \\ ${ }^{3}$ Universitas Muhammadiyah Prof. DR. HAMKA \\ benny_hendriana@uhamka.ac.id
}

\begin{abstract}
ABSTRAK
Tujuan penelitian ini adalah mengembangkan buku ajar matematika berbasis High Order Thingking Skill (HOTS) untuk siswa kelas X semester ganjil dan meningkatkan kualitas bahan ajar dilihat dari aspek validitas. Penelitian ini merupakan menggunakan model Analysis, Design, Development, Implementation, and Evaluation (ADDIE). Produk penelitian ini berupa buku ajar matematika berbasis HOTS. Hasil penelitian menunjukkan bahwa buku ini memiliki kualitas yang baik dilihat dari beberapa aspek, antara lain hasil penilaian oleh ahli materi menunjukkan kriteria valid atau baik (skor 70,70), hasil penilaian oleh pakar media menunjukkan kriteria sangat valid atau sangat baik (skor 95,14), hasil penilaian oleh pakar bahasa menujukkan kriteria sangat valid atau sangat baik (skor 89,58), dan hasil penilaian oleh guru matematika SMA menunjukan kriteria sangat valid atau sangat baik (skor 89,58).
\end{abstract}

Kata Kunci: buku ajar, HOTS, matematika SMA

\begin{abstract}
The aim of this study is to develop mathematics textbooks based on High Order Thinking Skills (HOTS) for odd grade X students and improve the quality of teaching materials in terms of validity. This research is a development with Analysis, Design, Development, Implementation, and Evaluation (ADDIE) model. The product of this research is HOTS-based mathematics textbooks. The results showed that this book has great quality based on several aspects, including valid or good criteria (score 70.70) as assessed by content experts; very valid or very good (score 95.14) as assessed by media experts; very valid or very good criteria (score 89.58 ) as assessed by linguists.
\end{abstract}

Keywords: Textbook, HOTS, high school mathematics

Format Sitasi: Rifdah., Nuriadin I., \& Hendriana, B. (2019). Pengembangan Buku Ajar Matematika Kelas X SMA Berbasis Hots. Kalamatika: Jurnal Pendidikan Matematika, 4(2), 163-176.

Penyerahan Naskah: 23 Agustus 2019 || Revisi: 9 November 2019 || Diterima: 11 November 2019 


\section{PENDAHULUAN}

Hasil studi Programme for International Student Assessment (PISA) tahun 2015 yang menunjukkan Indonesia baru bisa menduduki peringkat ke 69 dari 76 negara dengan skor 386 (Arifin, Kurniasih, \& Kurniawan, 2019), (Charmila, Zulkardi, \& Darmawijoyo, 2016). Peringkat rendah tersebut disebabkan oleh banyak faktor, diantaranya adalah kemampuan siswa di Indonesia pada umumnya belum mampu menyelesaikan soal-soal HOTS (High Order Thinking Skill) yang menuntut kemampuan penalaran, logika, analisis, evaluasi, dan kreatif yang merupakan kemampuan berpikir matematis tingkat tingi(Susanto \& Retnawati, 2016).

Kemampuan berpikir matematis tingkat tinggi tidak dapat tercapai sendirinya tanpa adanya upaya, fasilitas dan media yang memadai (Dinni, 2018). Salah satu fasilitas tersebut adalah buku ajar. Kurikulum 2013 dirancang untuk mengembangkan potensi siswa dalam ranah pegetahuan, keterampilan, dan sikap secara utuh. Prosesnya dilaksanakan dengan mengintegrasikan tiga ranah tersebut kedalam pendekatan pembelajaran matematika. Selain itu, tujuan kurikulum 2013 mencakup empat kompetensi, yaitu kompetensi, sikap sosial, sikap spiritual, pengetahuan, dan keterampilan (Michie, 2017).

Rumusan kompetensi sikap spiritual yaitu "Menghayati dan mengamalkan ajaran agama yang dianutnya”. Rumusan Kompetensi Sikap Sosial yaitu, "Menunjukkan perilaku jujur, disiplin, tanggung jawab, peduli kerjasama, santun, responsif, dan pro-aktif sebagai bagian dari solusi atas permasalahan dalam proses interaksi di lingkungan sosial" (El Iq Bali, 2017). Kedua kompetensi tersebut dapat dicapai dengan pembelajaran tidak langsung (indirect teaching), yaitu pembiasaan, keteladanan, dan budaya sekolah dengan memperhatikan karakteristik mata pelajaran, dan kondisi peserta didik (Grant, Jeon, \& Buettner, 2019). Kompetensi pengetahuan terdiri dari kemampuan Memahami, menerapkan, dan menganalisis pengetahuan faktual, konseptual, dan prosedural berdasarkan ilmu pengetahuan, teknologi, seni, budaya, dan humaniora dengan wawasan kemanusiaan, kebangsaan, dan kenegaraan. Keterampilan terdiri dari ranah konkret dan ranah abstrak dan pengembangan dari apa yang dipelajari siswa di sekolah secara mandiri, dan mampu menerapkannya (Setiadi, 2016).

Kompetensi inti pada buku ajar matematika yang digunakan di sekolah-sekolah seringkali hanya memuat kompetensi inti 3 saja yakni pengetahuan seharusnya memuat kompetensi inti 4 yakni keterampilan. Hal ini terlihat dari pemberian contoh soal yang disertai jawaban, seharusnya tidak perlu diberikan jawaban atau kemas dalam bentuk suatu kegiatan 
sehingga siswa lebih terampil dan memuat kompetensi inti 4. Buku ajar matematika pada umumnya seperti pada Gambar 1.

5. Ubah bentuk $|2 x-1|$ dan $|x+3|$ dengan menggunakan Definisi 1.1, sehingga diperoleh:

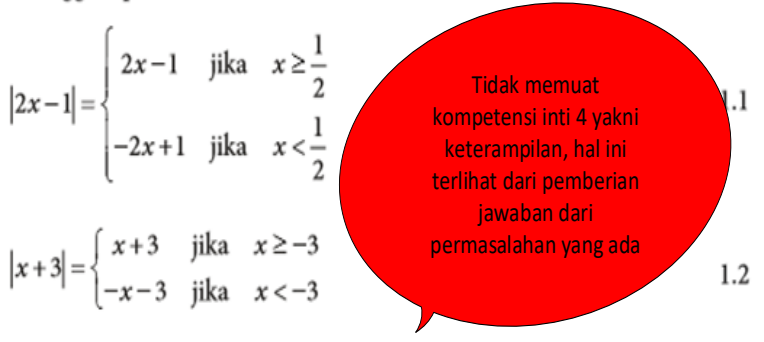

Berdasarkan sifat persamaan, bentuk $|2 x-1|=|x+3|$, dapat dinyatakan menjadi $|2 x-1|-|x+3|=0$. Artinya, sesuai dengan konsep dasar "mengurang", kita dapat mengurang $|2 x-1|$ dengan $|x+3|$ jika syarat $x$ sama. Sekarang, kita harus memikirkan strategi agar $|2 x-1|$ dan $|x+3|$ memiliki syarat yang sama. Syarat tersebut kita peroleh berdasarkan garis bilangan berikut.

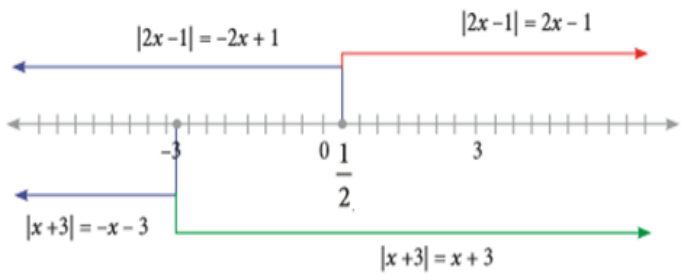

Gambar 1. Contoh Soal dan Alternatif Penyelesaian

Selain itu proyek yang dihadirkan pada beberapa buku ajar matematika hanya menghadirkan permasalahan sehingga kurang memfasilitasi keterampilan abad 21 yakni keterampilan berpikir kritis, kreatif, kolaboratif, dan inovatif (Wijaya, Sudjimat, \& Nyoto, 2016; Harjono et al., 2018). Adapaun proyek yang disajikan dalam buku ajar pada umumnya sebagai berikut.

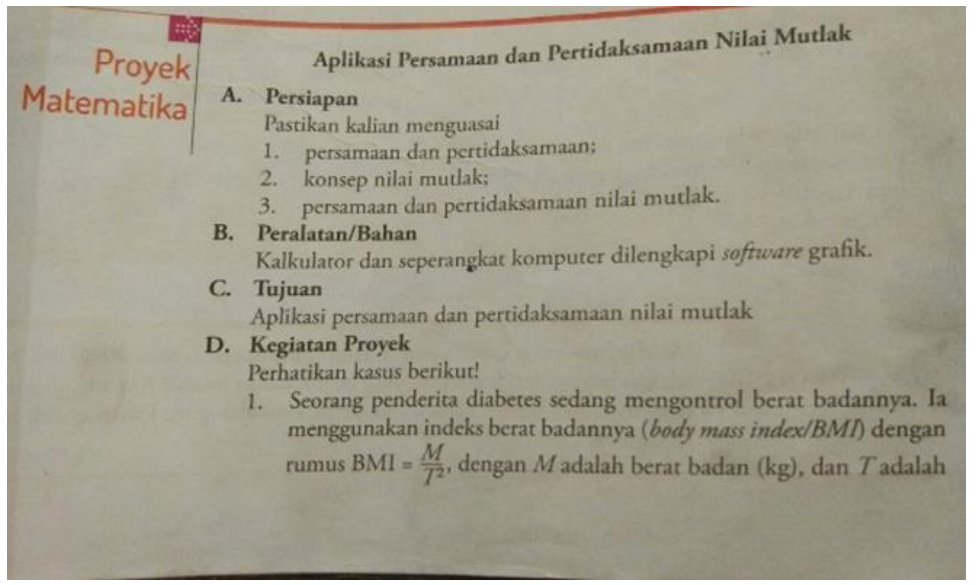

Gambar 2. Contoh Proyek Matematika Pada Buku Ajar 
Proyek yang dihadirkan seharusnya tidak hanya menghadirkan sebuah masalah lalu siswa hanya diminta untuk menyelesaikan permasalahan tersebut, sehingga kurang memfasilitasi keterampilan abad 21 siswa. Proyek yang dapat memfasilitasi keterampilan abad 21 siswa adalah proyek yang dapat membuat siswa mampu berpikir analisis, kritis, kreatif, inovatif, dan kolaboratif (Arifin, 2017).

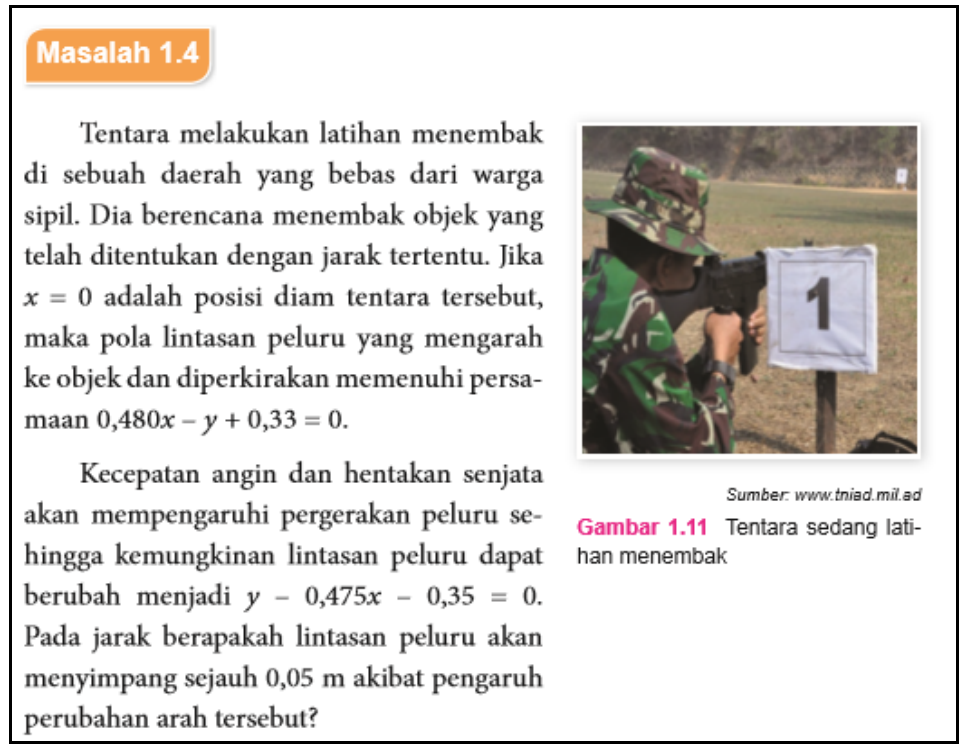

Gambar 3. Contoh Permasalahan Pada Buku Ajar

Masalah yang disajikan dalam buku ajar tersebut belum menyajikan materi yang dapat memfasilitasi kemampuan bepikir matematis tingkat tinggi karena hanya disajikan permasalahan yang sederhana yang dimulai dari contoh soal dan berakhir dengan latihan yang serupa. Permasalahan tersebut hanya berupa pemahaman konsep yang hanya dasar dari kemampuan berpikir tingkat tinggi (Hendriana, 2019). Adapun latihan soal yang digunakan dalam buku ajar pada umumnya sebagai berikut.

Selesaikan pertidaksamaan nilai mutlak berikut.
a) $|3-2 x|<4$
b) $\left|\frac{x}{2}+5\right| \geq 9$
c) $|3 x+2| \leq 5$
d) $\quad 2<\left|2-\frac{x}{2}\right| \leq 3$
e) $|x+5| \leq|1-9 x|$

Gambar 4. Contoh Latihan Pada Buku Ajar 
Contoh latihan yang tersedia pada buku ajar di atas memperlihatkan bahwa soal yang digunakan adalah soal-soal rutin yang bersifat sederhana yang dikatakan belum bisa memfasilitasi kemampuan berpikir tingkat tinggi. Soal-soal tersebut kurang melibatkan konsep matematis yang lain sehigga siswa terbiasa berpikir sederhana dan kurang mengembangkan pengetahuan awalnya.

Berdasarkan latar belakang yang telah dikemukakan di atas, maka keperluan untuk melakukan penelitian yang berfokus pada pengembangan buku ajar matematika berbasis High Order Thingking Skill (HOTS), dipandang oleh penulis merupakan langkah yang sangat perlu dan utama. Hal ini disebabkan karena buku ajar matematika yang memuat indikator-indikator berpikir matematis tingkat tinggi belum pernah dikembangkan. Sehingga gagasan ini diwujudkan dalam skripsi yang berjudul "Pengembangan Buku Ajar Matematika wajib Berbasis HOTS Untuk Siswa Kelas X SMA Semester Ganjil”.

\section{METODE PENELITIAN}

Metode penelitian yang digunakan pada penelitian ini adalah metode penelitian pengembangan (Research and Development model pengembangan ADDIE, yaitu model pengembangan yang terdiri dari lima tahapan yaitu, Analysis (analisis), Design (desain), Development (pengembangan), Implementation (implementasi), dan Evaluating (evaluasi) (Pribadi, 2016). Adapun alur pengembangan dapat dilihat pada Gambar 4. di bawah ini.

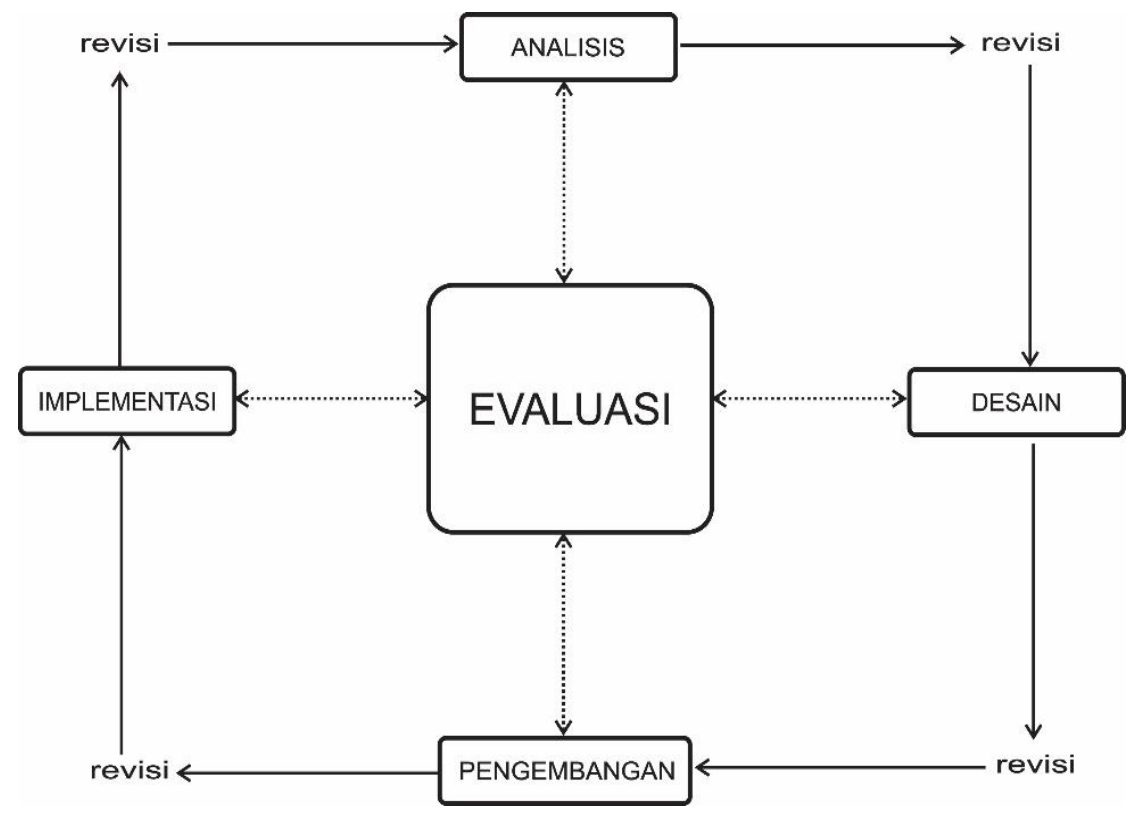

Gambar 4. Contoh Latihan Pada Buku Ajar 
Instrumen yang digunakan dalam penelitian ini adalah angket, dimana digunakan untuk mengetahui tingkat kelayakan dari produk yang dikembangkan. Angket disusun dalam 4 kategori jawaban yaitu sangat kurang, kurang, baik, dan sangat baik. Angket digunakan untuk memvalidasi dari ahli materi, media, serta bahasa dari produk yang dkembangkan. Setelah data dari angket terkumpul, data kemudian dianalisis. Data dari hasil validasi ahli materi, ahli media, ahli bahasa, serta guru diberikan skor berdasarkan Tabel 1. dibawah ini:

Tabel 1. Kriteria Pensekoran Angket

\begin{tabular}{lc}
\hline \multicolumn{1}{c}{ Katagori } & Skor \\
\hline Sangat Kurang & 1 \\
Kurang & 2 \\
Baik & 3 \\
Sangat Baik & 4 \\
\hline
\end{tabular}

Untuk mendeskripsikan hasil penskoran, maka hasil angket dihitung dengan menggunakan rumus di bawah ini:

$P=\frac{A}{M} \times 100 \%$

Keterangan:

$P \quad$ : Prosentase Skor

A : Jumlah Skor Reponden

M : Jumlah Skor Maksimum

Untuk mengintepretasikan hasil prosentase skor, maka berdasarkan klasifikasi skala pada Tabel 2 berikut.

Tabel 2. Kriteria Intepretasi Skor Skala Angket

\begin{tabular}{lc}
\hline \multicolumn{1}{c}{ Rentang } & Kriteria \\
\hline $0 \% \leq \mathrm{P} \leq 20 \%$ & Tidak Baik \\
$20 \%<\mathrm{P} \leq 40 \%$ & Kurang Baik \\
$40 \%<\mathrm{P} \leq 60 \%$ & Cukup \\
$60 \%<\mathrm{P} \leq 80 \%$ & Baik \\
$80 \%<\mathrm{P} \leq 100 \%$ & Sangat Baik \\
\hline
\end{tabular}

Bagian metode penelitian ini menguraikan langkah-langkah penyelesaian masalah. Uraikan dengan jelas prosedur penelitian yang dilakukan. Metode yang dipilih agar disesuaikan dengan jenis penelitiannya. Sebagai contoh penelitian eksperimen, desain penelitian, pengambilan populasi dan sampel serta prosedur pelaksanaan penelitian harus jelas.

\section{HASIL DAN PEMBAHASAN}

Sesuai dengan pengembangan ADDIE, prosedur yang dilakukan dalam penelitian pengembangan buku ajar meliputi 5 tahap, yaitu: Analysis, Design, Development, 
Implementation, dan Evaluation. Berikut ini merupakan penjelasan tahapan-tahapan yang telah dilakukan dalam pengembangan buku ajar.

\section{Tahap Analisis}

Berdasarkan observasi, siswa kelas X SMA rata-rata berusia 15-16 tahun. Siswa mampu menyelesaikan masalah Matematika yang abstrak dengan kemampuan bernalarnya. Minat siswa terhadap pembelajaran matematika tergolong baik. Setiap pembelajaran matematika, siswa antusias dan mau menyampaikan pendapat dan bertanya terkait dengan materi yang sedang dipelajari. Kemampuan bekerja sama siswa dalam suatu kelompok belajar tergolong baik. Akan tetapi sebagian siswa tidak terampil dalam menyelesaikan suatu permasalahan di depan kelas, dan masih harus dituntun dalam proses penyelesaiannya. Selain itu, soal-soal yang diberikan adalah soal-soal yang rutin sehingga tidak memancing siswa untuk berpikir tingkat tinggi.

\section{Tahap Desain}

Hasil pada tahap analisis dijadikan sebagai dasar dalam membuat desain. Hal-hal yang dilakukan pada tahap desain yaitu menyusun peta kebutuhan buku ajar, menentukan struktur buku ajar, dan pembuatan instrument penilaian.

\section{Tahap Pengembangan}

Tahapan ini terdiri dari 2 macam proses, yaitu penulisan buku ajar, dan validasi buku ajar. Kedua proses tersebut diuraikan sebagai berikut. Dalam penulisan bahan ajar, peneliti mengacu pada pedoman penulisan bahan ajar dilihat dari komponen kelayakan isi, bahasa, penyajian, dan kegrafikaan. Selain itu penulisan bahan ajar juga mengacu kepada kriteria HOTS, dimana soal-soal yang diberikan bukanlah soal-soal rutin melainkan soal-soal yang mampu meningkatkan kemampuan berpikir tingkat tinggi siswa. Penulisan bahan ajar menggunakan beberapa program aplikasi komputer yaitu Microsoft Office Word 2007, Visio 2013 , Geogebra, Adobe Photoshop, dan Snipping Tool.

Draf bahan ajar yang dihasilkan pada tahap pengembangan selanjutnya divalidasi oleh ahli materi, ahli media, dan ahli bahasa. Buku ajar divalidasi oleh ahli materi dari dosen pendidikan matematika Universitas Muhammadiyah Prof DR. Hamka (UHAMKA), divalidasi oleh ahli media dari Pusat Kurikulum dan Perbukuan, dan divalidasi oleh ahli bahasa dari tim penulis buku Duta. Validasi yang dilakukan validator (ahli materi, ahli media, dan ahli bahasa) 
yaitu penilaian bahan ajar pada setiap aspek yang ditanyakan pada lembar penilaian dilihat dari komponen kelayakan isi, kelayakan bahasa, kelayakan penyajian, dan kelayakan kegrafikaan. Selain itu, dalam validasi ini validator memberi komentar dan saran untuk perbaikan bahan ajar. Pada bagian akhir validasi, validator memberi kesimpulan berkaitan dengan kelayakan bahan ajar secara keseluruhan untuk diuji-cobakan. Berikut kriteria pensekoran nilai yang digunakan dalam proses validasi.

\section{Hasil Validasi Ahli Materi}

Produk pengembangan yang diserahkan kepada ahli Materi adalah berupa buku ajar. Paparan deskriptif hasil validasi ahli materi akan ditunjukkan melalui metode kuisioner dengan instrument angket. Hasil penilaian ahli materi buku ajar mendapatkan presentase ratarata $83,3 \%$ pada indikator pencapaian kesesuaian materi dengan SK dan KD, materi yang terdapat pada buku ajar matematika berbasis HOTS sudah sesuai dengan SK dan KD pembelajaran matematika kurikulum 2013 revisi. Pada indikator pencapaian keakuratan materi buku ajar mendapat presentase rata-rata 62,5\%, butir penilaian keakuratan konsep dan definisi mendapat skor 2 keakuratan prinsip mendapat skor 2, keakuratan fakta dan data mendapat skor 2, dikarenakan pada saat validasi penulis tidak menyantumkan sumber dari beberapa informasinformasi yang ada pada buku ajar matematika berbasis HOTS.

Pada indikator pencapaian pendukung materi pembelajaran memperoleh presentase $75 \%$, butir mendorong untuk mencari informasi lebih jauh memperoleh skor 2, dikarenakan terdapat beberapa konten materi yang sederhana sehingga kurang dapat memfasilitasi siswa dalam mencari informasi lebih jauh.

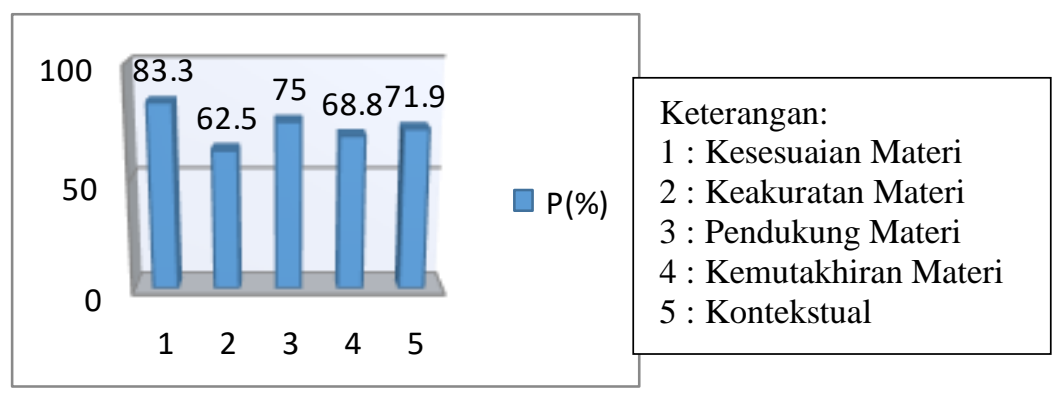

Gambar 5. Diagram batang hasil validasi ahli materi

Berdasarkan Gambar 5 hasil validasi ahli materi sebesar 70,7\% dan dinyatakan baik. Kritik dan saran yang diberikan adalah agar memperhatikan defnisi dan teorema dari konsep yang digunakan. Perlu menggunakan buku Kalkulus sebagai panduan untuk menjelaskan suatu 
kosep. Berdasarkan kritik dan saran tersebut, dituliskan bahwasannya ada beberapa aspek yang perlu direvisi atau diperbaiki sebagai bahan pertimbangan apakah produk layak untuk diujicobakan ataukah tidak, serta sebagai penyempurnaan produk sehingga dapat menjadi lebih berkualitas, dalam perbaikan buku ajar ini memerlukan 1 kali revisi.

\section{Hasil Validasi Ahli Media}

Paparan deskriptif hasil validasi ahli media terhadap produk pengembangan buku ajar matematika berbasis HOTS ditunjukkan melalui metode kuisioner dengan instrument angket. Hasil penilaian ahli media mendapat presentase rat-rata $100 \%$ pada indikator pencapaian ukuran buku, dikarenakan ukuran buku matematika berbasis HOTS sudah sesuai dengan standar yaitu B5. Pada indikator pencapaian desain sampul buku memperoleh presentase ratarata $80 \%$. Pada indikator pencapaian desain isi buku memperoleh presentase 90,6\% dikarenakan pemisahan anatar paragraph yang kurang jelas.

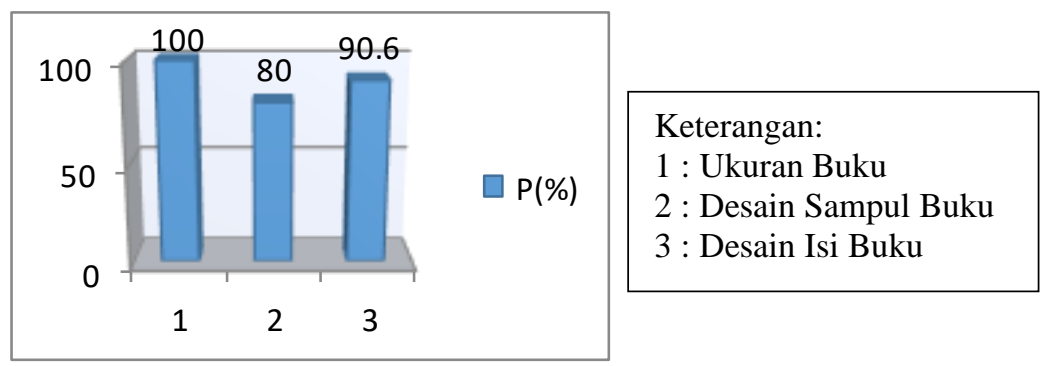

Gambar 6. Diagram batang hasil validasi ahli media

Berdasarkan Gambar 6 hasil validasi ahli media sebesar 95,14\% dan dinyatakan Sangat baik. Berikut adalah paparan data kualitatif yang dihimpun dari kritik dan saran oleh pakar yang merupakan anggota tim penelaah buku sekolah nasional standar pendidikan di pusat kurikulum dan perbukuan sebagai ahli media. Kritik dan saran yang diberikan adalah buku ini sebagian besar sudah cukup baik dari segi layout, konten, grafika, dan konsistensi tetapi hanya perlu perbaikan pada kesalahan ketik.

Berdasarkan kritik dan saran tersebut, dituliskan bahwasannya ada beberapa aspek yang perlu direvisi atau diperbaiki sebagai bahan pertimbangan apaka produk layak untuk diujicobakan ataukah tidak, serta sebagai penyempurnaan produk sehingga dapat menjadi lebih berkualitas, dalam perbaikan buku ajar ini memerlukan 1 kali revisi. 


\section{Hasil Validasi Ahli Bahasa}

Produk pengembangan yang diserahkan kepada ahli bahasa adalah berupa buku ajar matematika berbasis HOTS. Paparan deskriptif hasil validasi ahli bahasa akan ditunjukkan melalui metode kuisioner dengan instrument angket. Hasil penilaian buku ajar matematika berbasis HOTS oleh ahli bahasa memperoleh presentase rata-rata $75 \%$ pada indikator pencapaian lugas, hal ini dikarenakan terdapak kalimat-kalimat yang kurang efektif. Pada indikator pencapaian komunikatif memperoleh presentase rata-rata 100\% dikarenakan bahasa yang digunakan dalam buku ajar sudah menggunakan bahasa yang komunikatif dan mudah dimengerti. Pada indikator pencapaian kesesuaian dengan kaidah bahasa memperoleh presentase rata-rata $75 \%$ dikarenakan terdapat beberapa kata yang kurang tepat ejaannya.

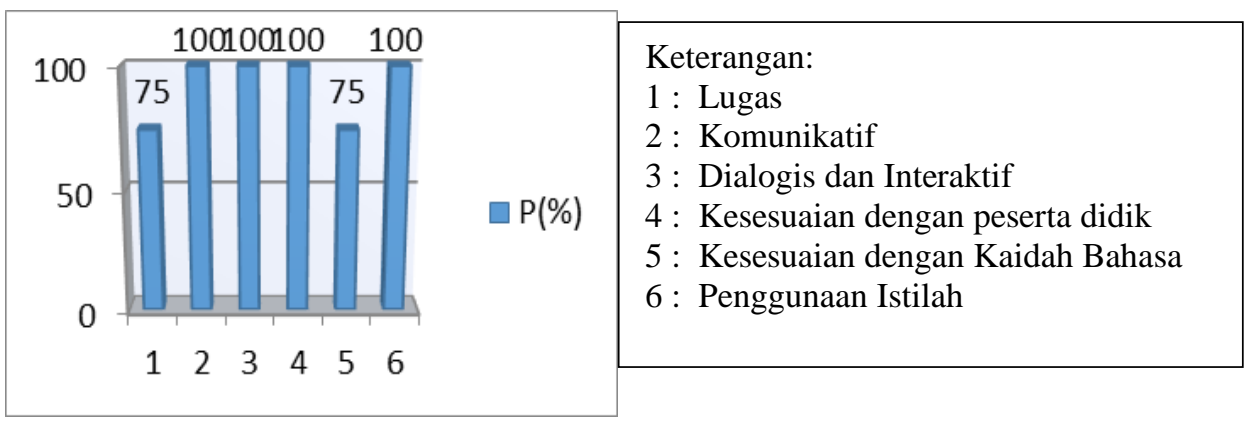

Gambar 7. Diagram batang hasil validasi ahli bahasa

Berdasarkan hasil perhitungan di atas hasil validasi ahli bahasa sebesar $89.58 \%$ dan dinyatakan sangat valid. Berikut adalah paparan data kualitatif yang dihimpun dari kritik dan saran oleh pakar yang merupakan penulis buku Duta sebagai ahli bahasa. Kritik dan saran yang diberikan adalah dilihat dari penggunaan bahasa, buku ini sudah baik, hanya perlu perbaikan untuk beberapa kata yang salah pengetikannya.

Berdasarkan kritik dan saran tersebut, dituliskan bahwasannya ada beberapa aspek yang perlu direvisi atau diperbaiki sebagai bahan pertimbangan apaka produk layak untuk diujicobakan ataukah tidak, serta sebagai penyempurnaan produk sehingga dapat menjadi lebih berkualitas, dalam perbaikan buku ajar ini memerlukan 1 kali revisi.

\section{Tahap Implementasi}

Pada tahapan ini buku ajar hasil uji validasi oleh ahli materi, ahli media, dan ahli Bahasa diujicobakan. Karena keterbatasan waktu, penelitian ini diujicobakan atau divalidasi hanya oleh guru matematika di sekolah. Produk pengembangan yang diserahkan kepada guru matematika adalah berupa buku ajar matematika berbasis HOTS. Paparan deskriptif hasil 
validasi ahli materi akan ditunjukkan melalui metode kuisioner dengan instrument angket. Hasil penilaian buku ajar matematika berbasis HOTS oleh guru matematika memperoleh presentase rata-rata $83,3 \%$ pada indikator kesesuaian materi dengan SK dan KD. Pada indikator keakuratan materi memperoleh presentase rata-rata 78,1\%, dikarenakan terdapat informasi yang tidak dicantumkan sumbernya.

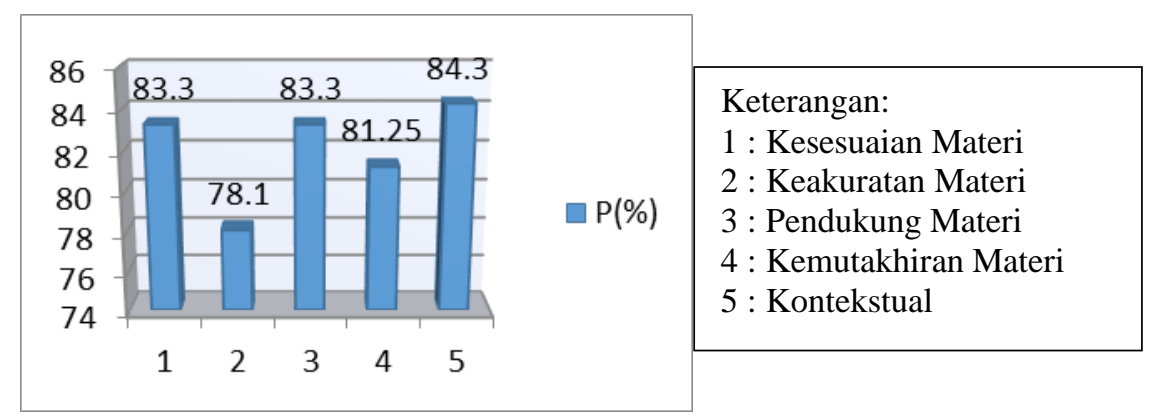

Gambar 8. Diagram batang hasil validasi guru matematika

Berdasarkan hasil perhitungan di atas hasil validasi guru matematika sebesar 81,9\% dan dinyatakan sangat valid. Berikut adalah paparan data kualitatif yang dihimpun dari kritik dan saran oleh guru matematika di Jakarta. Kritik dan saran yang diberikan adalah Tambahkan pembuatan grafik fungsi nilai mutlak dengan pergeseran.

Berdasarkan kritik dan saran tersebut dituliskan bahwasannya ada beberapa aspek yang perlu direvisi atau diperbaiki sebagai bahan pertimbangan apaka produk layak untuk diujicobakan ataukah tidak, serta sebagai penyempurnaan produk sehingga dapat menjadi lebih berkualitas, dalam perbaikan buku ajar ini memerlukan 1 kali revisi.

\section{Tahap Evaluasi}

Berdasarkan penilaian para ahli baik ahli materi, ahli media, ahli Bahasa, dan guru matematika yang mengajar di SMA. Buku ajar matematika berbasis HOTS, rata-rata mendapat nilai baik, walaupun masih ada beberapa revisi untuk menyempurnakannya.

\section{KESIMPULAN}

Buku ajar matematika berbasis HOTS untuk siswa SMA kelas X pada semester ganjil berhasil dikembangkan dan siap diujicobakan ke siswa karena sudah memenuhi uji validitas baik dari ahli materi, ahli media, ahli Bahasa, dan guru di sekolah. Dari beberapa proses uji validitas buku dinyatakan dalam kondisi baik. Guru diharapkan dapat menggunakan buku ini 
untuk melatih kemampuan berpikir tingkat tinggi siswa, untuk meningkatkan kualitas sumber daya manusia yang mampu berdaya saing global.

\section{REFERENSI}

Arifin, Z. (2017). Mengembangkan Instrumen Pengukur Critical Thinking Skills Siswa pada Pembelajaran Matematika Abad 21. Theorems, 1(2), 92-100. https://doi.org/10.1016/j.neulet.2013.10.065

Arifin, Z., Kurniasih, N., \& Kurniawan, H. (2019). Kemampuan Metakognisi Siswa Climber Dalam Memecahkan Masalah Matematika Soal Pisa. Seminar Nasional Pendidikan Matematika Ahmad Dahlan, 6(0), 301-308. Retrieved from http://seminar.uad.ac.id/index.php/sendikmad/article/view/717

Charmila, N., Zulkardi, Z., \& Darmawijoyo, D. (2016). Pengembangan Soal Matematika Model Pisa Menggunakan Konteks Jambi. Jurnal Penelitian Dan Evaluasi Pendidikan, 20(2), 198. https://doi.org/10.21831/pep.v20i2.7444

Dinni, H. N. (2018). HOTS ( High Order Thinking Skills ) dan Kaitannya dengan Kemampuan Literasi Matematika. Prisma, 1, 170-176.

El Iq Bali, M. M. (2017). Model Interaksi Sosial Dalam Mengelaborasi Keterampilan Sosial. Jurnal Pedagogik, 04(02), 211-277.

Grant, A. A., Jeon, L., \& Buettner, C. K. (2019). Chaos and commitment in the early childhood education classroom: Direct and indirect associations through teaching efficacy. Teaching and Teacher Education, 81, 50-60. https://doi.org/10.1016/j.tate.2019.02.010

Harjono, A., Syukur, A., Bahri, S., Studi, P., Fisika, P., Mataram, U., ... Thinking, C. (2018). Jurnal Ilmiah Profesi Pendidikan Identifikasi Kesiapan LKPD Guru Terhadap Keterampilan Abad 21 Pada Pembelajaran IPA SMP Jurnal Ilmiah Profesi Pendidikan. Jurnal Ilmiah Profei Pendidikan, 3(2), 124-128. 
Hendriana, B. (2019). Lembar Kerja Peserta Didik Berbasis Cabri 3d Untuk Meningkatkan Pemahaman Konsep Matematis Siswa. AKSIOMA, 8(1), 112-120. https://doi.org/https://doi.org/10.24127/ajpm.v8i1.1740

Michie, M. (2017). Comparing the Indonesian Kurikulum 2013 with the Australian Curriculum: Focusing on science for junior secondary schools. International Education Journal: Comparative Perspectives, 16(2), 83-96.

Setiadi, H. (2016). Pelaksanaan Penilaian Pada Kurikulum 2013. Jurnal Penelitian dan Evaluasi Pendidikan, 20(2), 166. https://doi.org/10.21831/pep.v20i2.7173

Susanto, E., \& Retnawati, H. (2016). Perangkat pembelajaran matematika bercirikan PBL untuk mengembangkan HOTS siswa SMA. Jurnal Riset Pendidikan Matematika, 3(2), 189. https://doi.org/10.21831/jrpm.v3i2.10631

Wijaya, E. Y., Sudjimat, D. A., Nyoto, A., \& Malang, U. N. (2016). Transformasi pendidikan abad 21 sebagai tuntutan pengembangan sumber daya manusia di era global. In Prosiding Seminar Nasional Pendidikan Matematika (Vol. 1, No. 26, pp. 263-278). 
